\title{
HUBUNGAN DUKUNGAN KELUARGA DENGAN TINGKAT STRES MAHASISWA KEPERAWATAN PADA PENYUSUNAN KARYA ILMIAH
}

\section{The Correlation Of Family Support With Nursing Student Stress Level In Scientific Paper Preparation}

\author{
Hubertus Agung Pambudi ${ }^{1}$, Deola Putra Wahyu Gunawan ${ }^{2}$, Kandar $^{3}$ \\ ${ }^{1}$ Departemen Keperawatan Jiwa, STIKes st.Elisabeth, Semarang, Jawa Tengah, Indonesia \\ ${ }^{2}$ Mahasiswa S1 Ilmu Keperawatan, STIKes St.Elisabeth, Semarang, Indonesia \\ ${ }^{3}$ Program Studi $S 1$ imu keperawatan, STIKes St.Elisabeth, Semarang, Indonesia \\ Korespondensi : hagungpambudi@gmail.com
}

\begin{abstract}
ABSTRAK
Dukungan keluarga adalah sikap, tindakan, dan penerimaan keluarga. Dukungan keluarga yang adekuat terbukti dapat meningkatkan fungsi kognitif dan kesehatan emosi, karena dukungan keluarga merupakan unsur terpenting dalam membantu individu menyelesaikan masalah. Dukungan keluarga yang diberikan meliputi dukungan emosional, instrumental, informasional, dan penilaian. Stress merupakan reaksi terhadap faktor fisik, psikologis, atau sosial yang mempengaruhi kesehatan jasmani atau rohani. Tujuan penelitian ini untuk membuktikan adanya hubungan dukungan keluarga dengan tingkat stress dalam penyusunan karya ilmiah pada mahasiswa D-III keperawatan STIKes St. Elisabeth Semarang. Desain penelitian ini adalah kuantitatif cross sectional. Sampel penelitian 33 responden dengan teknik total sampling. Data diperoleh dengan menggunakan kuesioner dukungan keluarga dan kuesioner depression anxiety stress scale. Data dianalisis dengan uji chi-square. Hasil uji chisquare menunjukkan bahwa tidak ada hubungan dukungan keluarga dengan tingkat stress dalam penyusunan karya ilmiah pada mahasiswa D-III keperawatan STIKes St. Elisabeth Semarang. Mahasiswa diharapkan mampu beradaptasi dan melakukan koping yang positif dan konstruktif.
\end{abstract}

Kata Kunci: dukungan keluarga, stress, karya ilmiah.

\section{ABSTRACT}

Family support is an attitude, action, and acceptance of the family. Adequate family support is proven to improve cognitive function and emotional health, because family support is the most important element in helping individuals solve problems. Family support provided includes emotional, instrumental, informational, and assessment support. Stress is a reaction to physical, psychological, or social factors that affect physical or spiritual health. The purpose of this study was to prove the correlation of family support with nursing student stress level in scientific paper preparation D-III nursing students of STIKes St Elisabeth Semarang. The design of this research is quantitative cross sectional. The research sample was 33 respondents with total sampling technique. Data were obtained using a family support questionnaire and depression anxiety stress scale questionnaire. Data were analyzed using the chi-square test. The results of the chi-square test show that there is no relationship between family support and stress levels in the preparation of final assignments for D-III nursing students STIKes St.Elisabeth Semarang. Students are expected to be able to adapt and do positive and constructive coping.

Keywords: family support, stress, scientific paper 
Hubertus Agung Pambudi, dkk: Hubungan Dukungan Keluarga Dengan Tingkat Stres Mahasiswa Keperawatan Pada Penyusunan Karya Ilmiah

\section{PENDAHULUAN}

Mahasiswa mempunyai peranan penting dalam mewujudkan cita-cita dalam pembangunan nasional, karena mahasiswa dinilai memiliki tingkat intelektualitas yang tinggi, kecerdasan dalam berpikir dan terencana dalam bertindak (Maanesh, 2009). Mahasiswa dalam menempuh pendidikan tinggi, dihadapkan dengan karya ilmiah dalam bentuk karya tulis ilmiah. Setiap mahasiswa memiliki kemampuan yang berbeda serta keunikan pribadi yang berbeda untuk dapat menyelesaikan penyusunan karya tulis ilmiahnya. Mahasiswa sebagai individu memiliki kinerja, kecepatan belajar dan gaya belajar yang berbeda. (Papilaya \& Huliselan, 2016).

Data yang dikeluarkan oleh American College Health Association (2013), dari 32.964 sebanyak (27,9\%) mengalami masalah stress yang disebabkan tekanan dalam menyelesaikan karya ilmiah. Penelitian Saudi Arabia, diketahui bahwa prevalensi stress pada mahasiswa sebanyak $78,7 \%$ (Abdulghani, 2008). Dalam manajemen stress dapat dipengaruhi oleh faktor internal dan eksternal. Faktor internal didefinisikan sebagai faktor yang berasal dari individu sendiri. Faktor eksternal dapat berupa dukungan dari keluarga. Dukungan keluarga merupakan sebuah sikap, tindakan, dan penerimaan keluarga, keluarga juga berfungsi sebagai sistem pendukung bagi anggotanya dan anggota keluarga, keluarga yang bersifat mendukung akan selalu siap memberikan pertolongan dan bantuan. Dukungan dari keluarga merupakan unsur terpenting dalam membantu individu menyelesaikan masalah. Apabila ada dukungan, rasa percaya diri akan bertambah dan motivasi untuk menghadapi masalah yang terjadi akan meningkat (Muhith \& Siyoto, 2016).

Peran orang tua dalam pendidikan dengan memberikan dukungan bagi seorang anak yang sedang menempuh pendidikan dapat memberi pengaruh dalam belajar anak. Orang tua yang mendukung sekolah anak tentu akan berusaha memenuhi segala kebutuhan anak yang berhubungan dengan dunia belajarnya. Selain pemenuhan fasilitas, orang tua juga harus memberi pengertian serta dorongan kepada anak untuk belajar. Orang tua wajib memberi pengertian dan mendorongnya untuk mengatasi kesulitan yang dialami anak pada masa pendidikan (Subini, 2012).

Penelitian yang dilakukan Sari (2016), pada mahasiswa 64 Fakultas Kedokteran Universitas Tanjungan Pontianak angkatan tahun 2009 - 2011 menemukan, dukungan keluarga dapat berupa dukungan emosional, dukungan penilaian, dukungan informasi, dan dukungan instrumental. Berdasarkan penelitian dukungan keluarga yang baik berjumlah 36 responden $(56,3 \%)$,dan dukungan keluarga yang buruk berjumlah 28 responden $(43,8 \%)$. Hasil wawancara peneliti pada 8 mahasiswa D3 keperawatan semester akhir didapatkan data bahwa stress pada mahasiswa yang sedang melaksanakan penyusunan karya ilmiah, disebabkan beberapa hal seperti merasa dibebani yang mengakibatkan kehilangan motivasi dan minimnya dukungan dari keluarga.

Berdasarkan latar belakang tersebut maka peneliti tertarik mendalami lebih jauh dari hubungan dukungan keluarga dengan tingkat stress mahasiswa yang sedang menyusun karya tulis ilmiah sebagai bentuk karya ilmiah.

\section{TUJUAN PENELITIAN}

Adapun tujuan penelitian ini adalah untun mengetahui hubungan dukungan keluarga dengan tingkat stress dalam penyusunan karya ilmiah pada mahasiswa D- III STIKes St. Elisabeth Semarang.

\section{METODE PENELITIAN}

Desain

Penelitian ini merupakan jenis penelitian kuantitatif cross sectional dimana variabel dependent dan independent diidentifikasi pada satu satuan waktu.

\section{Populasi dan Sampel}

Populasi yang digunakan untuk penelitian ini adalah seluruh mahasiswa DIII tingkat 3 yang sedang menyusun Karya 
Hubertus Agung Pambudi, dkk: Hubungan Dukungan Keluarga Dengan Tingkat Stres Mahasiswa Keperawatan Pada Penyusunan Karya Ilmiah

ilmiah sebanyak 33 mahasiswa di STIKes St. Elisabeth Semarang. Pada penelitian ini jenis pengambilan sampel yang digunakan adalah total sampling.

Tempat dan Waktu Penelitian

Pengambilan data ini dilaksanakan di

STIKes St. Elisabeth Semarang. Pengambilan data penelitian dilakukan selama 2 minggu.

\section{Instrumen dan Prosedur Pengukuran}

Penelitian ini menggunakan

instrumen berupa kuesioner dukungan keluarga, pertanyaan 1-6 dukungan emosional, pertanyaan 7-11 dukungan instrumental, pertanyaan 12-17 dukungan informasional, pertanyaan 18-24 dukungan penilaian. Kuesioner dukungan keluarga memiliki 24 pertanyaan dimana jawaban yang tersedia, yaitu "ya" atau "tidak". Kuesioner stress menggunakan depression anxiety and stress scale (DASS 21) untuk mengukur tingkat stress mahasiswa. Kuesioner DASS 21 untuk jawaban "ya" mendapat skor 1, untuk jawaban "tidak" mendapat skor 0 .

\section{Analisa Data}

Analisia data yang dilakukan pada penelitian ini adalah analisis univariat dan bivariate. Analisis univariat yang dianalisis mencakup dukungan keluarga seperti dukungan instrumental, informasional, penilaian, dan emosional, tingkat stress, jenis kelamin. Analisis bivariat menggunakan analisis komparatif dengan uji chi square.

\section{HASIL PENELITIAN}

Adapun gambaran distribusi responden sebagai berikut :

Table 1

Karakteristik Responden $(\mathrm{n}=33)$

\begin{tabular}{ccc}
\hline $\begin{array}{c}\text { Karakteristik } \\
\text { Responden }\end{array}$ & f & $\mathbf{\%}$ \\
\hline Jenis Kelamin & & \\
Laki - laki & 2 & 6 \\
Perempuan & 31 & 94 \\
$\begin{array}{c}\text { Dukungan Keluarga } \\
\text { Kurang }\end{array}$ & 1 & 3 \\
Cukup & 27 & 82
\end{tabular}

\begin{tabular}{ccc} 
Baik & 5 & 15 \\
Tingkat Stress & & \\
Normal & 4 & 12 \\
Ringan & 1 & 3 \\
Sedang & 7 & 21 \\
Berat & 21 & 64 \\
\hline
\end{tabular}

Berdasarkan tabel 1 tentang karakteristik berdasarkan jenis kelamin responden yang paling banyak adalah perempuan sebanyak 31 responden $(94 \%)$. Karakteristik berdasarkan dukungan keluarga sebanyak 27 responden mendapatkan dukungan keluarga yang cukup (82\%). Karakteristik berdasarkan tingkat stress sebanyak 21 responden mengalami tingkat stress berat (64\%).

\section{Tabel 2}

Hubungan Dukungan Keluarga Dengan Tingkat Stress Dalam Penyusunan Karya ilmiah $(n=33)$

\begin{tabular}{cccccc}
\hline Dukunga & \multicolumn{5}{c}{ Tingkat stress } \\
\cline { 2 - 5 }$n$ & Normal & Ringan & Sedang & Berat & p- \\
\cline { 2 - 5 } keluarga & $\mathrm{f}(\%)$ & $\mathrm{f}(\%)$ & $\mathrm{f}(\%)$ & $\mathrm{f}(\%)$ & value \\
\hline Kurang & $0(0)$ & $0(0)$ & $0(0)$ & $1(3)$ & \\
Cukup & $3(9)$ & $1(3)$ & $6(18)$ & $17(51)$ & 0,983 \\
Baik & $1(3)$ & $0(0)$ & $1(3)$ & $3(9)$ & \\
\hline
\end{tabular}

Berdasarkan tabel 2 dari 33 responden yang memiliki dukungan keluarga kurang terhadap tingkat stress normal yaitu $0 \%($ responden 0$)$, tingkat stress ringan $0 \%$ (responden 0 ), tingkat stress sedang $0 \%$ (responden 0 ), tingkat berat 3\%. Dukungan keluarga cukup terhadap tingkat stress normal $9 \%$, tingkat stress ringan $3 \%$, tingkat stress sedang $18 \%$, tingkat sress berat $51 \%$. Dukungan keluarga baik terhadap tingkat stress normal $3 \%$, tingkat stress ringan $0 \%$, tingkat stress sedang 3\%, tingkat stress berat $9 \%$. Hasil uji chi square didapatkan nilai $p=0,983$ $(\alpha>0,05)$.

\section{PEMBAHASAN}

Penelitian ini menunjukkan bahwa mahasiswa D III tingkat 3 STIKes St. Elisabeth Semarang mayoritas berjenis kelamin perempuan, selain itu hal yang menyebabkan perempuan lebih rentan mengalami stress daripada pria adalah 
karena secara fisiologis, otak wanita lebih kecil, otak perempuan bekerja $7-8$ kali lebih keras dibanding pria pada saat menghadapi masalah. Faktor lain yang menyebabkan wanita lebih sering mengalami stress yaitu, pada pria lebih mampu melepaskan diri dari pengaruh kortisol yang dilepaskan selama berlangsungnya stress, dibandingkan dengan kaum wanita, sehingga mereka lebih mudah memulihkan semangat dan melupakan stress yang dirasakan daripada wanita (Sari, 2016).

Stress yang dirasakan mahasiswa DIII tingkat 3 STIKes St. Elisabeth Semarang dapat disebabkan karena minimnya informasi yang diperoleh terkait tema karya ilmiah yang diperoleh. Hasil penelitian ini menunjukkan tidak ada korelasi antara dukungan keluarga dengan stress mahasiswa yang sedang menyusun karya ilmiah akhir. Dukungan Informasi diperlukan mahasiswa dalam menyusun karya ilmiah, dukungan informasi membantu mahasiswa dalam mendapat informasi yang berguna dalam penyusunan karya ilmiah (Setiadi, 2008).

Selama pengerjaan karya ilmiah, sumber stress yang dialami mahasiswa berasal dari stressor psikologis seperti kekhawatiran, dan tekanan batin untuk segera menyelesaikan karya ilmiah (Sunaryo, 2004). Mahasiswa kesulitan dalam manajemen waktu antara ingin mengerjakan karya ilmiah atau tugas praktek rumah sakit, karena tugas praktek rumah sakit seperti asuhan keperawatan sebanyak, pendidikan kesehatan, evidence based practice (EBP), dan melakukan ujian klinik dan ujian praktik. Selain itu, mahasiswa juga mempunyai tanggal maksimal sidang, yang membuat mahasiswa stress, dan khawatir. Apabila mahasiswa melewati batas maksimal sidang, mahasiswa akan berdampak pada kelulusan yang akan mengalami kemunduran. Jika mahasiswa tidak lulus bersama dengan rekan-rekannya, mahasiswa akan malu dengan teman-teman dan akan malas bertemu dengan pembimbing (Rasmun, 2004).

Faktor lainnya ditengarai dapat disebabkan oleh pemilihan pembimbing.
Mahasiswa tidak dapat memilih pembimbing sesuai keinginan. Hal ini menjadikan beban pikiran bagi mahasiswa. Dosen pembimbing yang mempunyai jadwal padat, dosen pembimbing yang mendapat tugas diluar kampus, dan supervisi di rumah sakit, membuat mahasiswa susah dalam bertemu dengan dosen pembimbing (Januarti, 2009).

Perbedaan tingkat stress yang dialami mahasiswa dapat diakibatkan karena terdapat perbedaan individual dalam berespons terhadap stressor. Mahasiswa yang sulit menenangkan diri ketika menghadapi masalah-masalah kecil berkaitan dengan karya ilmiah akan mudah merasa kecewa dan merasa putus asa (Priyoto, 2019). Mahasiswa yang mengalami stress berat bisa terjadi akibat kekhawatiran dan tekanan, dimana tekanan berasal dari tuntutan orang tua yang harus menyelesaikan karya ilmiah dan kekhawatiran bila mahasiswa tidak dapat wisuda tepat waktu, tidak mendapatkan gelar serta harus dihadapkan dengan karya ilmiah sebagai syarat untuk lulus dan memperoleh gelar (Harmilawati., 2013).

\section{KESIMPULAN}

\section{Implikasi}

Tidak terdapat korelasi dukungan keluarga terhadap tingkat stress mahasiswa dalam penyusunan karya ilmiah. Dukungan informasi yang adekuat terkait teknis penyusunan karya ilmiah sangat penting dilakukan secara tepat dan komprehensif. Mahasiswa diharapkan dengan sendiri bisa melakukan koping yang konstruktif dalam penyusunan karya ilmiah, dan melihat hambatan sebagai sebuah tantangan, ketika melakukan konsultasi dengan pembimbing, maupun penulisan karya ilmiah sesuai dengan panduan karya ilmiah.

\section{Keterbatasan}

Peneliti menyadari terdapat kekurangan dalam penelitian ini, penelitian ini tidak bisa digeneralisasi karena populasi yang hanya 33 mahasiswa dari jenjang DIII. Diperlukan lagi penelitian lebih lanjut untuk populasi yang lebih banyak. 
Hubertus Agung Pambudi, dkk: Hubungan Dukungan Keluarga Dengan Tingkat Stres Mahasiswa Keperawatan Pada Penyusunan Karya Ilmiah

\section{DAFTAR PUSTAKA}

Abdulghani, H. M. (2008). Stress and Depression Among Medical Students: A Cross Sectional Study at a Medical College in Saudi Arabia. Pakistan Journal of Medical Sciences, 24(1), 12-17.

American College Health Association. (2013). Spring 2013 Reference Group Executive Summary. Acha.

Harmilawati. (2013). Konsep Dan Proses Keperawatan Keluarga. Sulawesi Selatan: Pustaka As Salam.

Januarti, R. (2009). Hubungan Antara Persepsi Terhadap Dosen Pembimbing Dengan Tingkat Stress Dalam Menulis Skripsi. Universitas Muhammadiyah Surakarta.

Maanesh, S. (2009). Siap Kuliah (1st ed.). Jakarta Selatan: Gagas Media.

Muhith, A., \& Siyoto, S. (2016). Pendidikan Keperawatan Gerontik. Yogyakarta: CV Andi Offset.

Papilaya, J. O., \& Huliselan, N. (2016). Identifikasi Gaya Belajar Mahasiswa. Jurnal Psikologi Undip, 15(1), 56.

Priyoto. (2019). Konsep Manajemen Stress. Yogyakarta: Nuha Medika.

Rasmun, N. (2004). Stress Koping dan Adaptasi. Jakarta: Sagung Seto.

Sari, S. (2016). Hubungan Dukungan Keluarga Terhadap Dukungan Keluarga Mahasiswa Dalam Penyusunan Skripsi Di Fakultas Kedokteran Universitas Tanjungpura Pontianak. Nursing Student of Nursing Department. Universitas Tanjungpura.

Setiadi. (2008). Konsep Dan Proses Keperawatan Keluarga. Yogyakarta: Graha Ilmu.

Subini, N. (2012). Psikologi Pembelajaran. Yogyakarta: Mentari Pustaka.

Sunaryo. (2004). Psikologi Untuk Keperawatan. Jakarta: EGC. 